\title{
MANAJEMEN PIUTANG PADA KOPERASI
}

\author{
Sugeng Suroso \\ STIMA KOSGORO
}

\section{ABSTRACT}

Receivables are concessions granted by the company to its customers to pay later on the sale of goods or services at the time of the sale. The objective of this article is to analyze the credit sales policy that will run cooperatives so that the cooperative managers can decide whether the sale of these loans remains eligible to run or cash sales. The method used is the analysis of data collected and from library research and applying the formulas related to accounts receivable in Microsoft Excel as a tool of analysis. It is hoped that the results can be used as decision-making for managers of cooperatives.

\section{PENDAHULUAN}

Salah satu cara untuk menaikkan volume penjualan yang banyak dilakukan oleh dunia bisnis adalah transaksi kredit, pemberian potongan atau diskon pada konsumen (baik anggota maupun non anggota koperasi) atau kombinasi di antara kedua hal tersebut. Penjualan secara kredit menyebabkan adanya piutang atau tagihan dan kemungkinan tanggungan risiko jika debitur tidak membayar utang sebagaimana mestinya.

Jika sebuah koperasi menetapkan pembayaran secara kredit, maka untuk mengendalikan piutang tersebut perlu ditetapkan kebijaksanaan kredit. Kebijakan kredit berhubungan dengan jangka waktu kredit. Penetapan jangka waktu kredit (credit terms) dapat berupa cash discount, periode discount dan periode credit. Koperasi perlu menetapkan periode kredit bagi seluruh anggotanya, karena jangka waktu kredit akan mempengaruhi volume penjualan, biaya dan profit. Kebijakan kredit yang dapat dilakukan koperasi antara lain kebijakan penjualan kredit tanpa diskon, penjualan kredit dengan diskon. Kebijakan tersebut kemudian dapat dijadikan sebagai standar kinerja koperasi.

Dengan adanya standar kinerja dalam kebijakan kredit tersebut, maka berdasarkan data penjualan tunai, profit margin, syarat penjualan dan penjualan yang dianggarkan, dapat dianalisis tentang kebijakan penjualan kredit tersebut layak dijalankan koperasi ataukah tetap dengan penjualan tunai. Analisis tersebut perlu dilakukan supaya koperasi dapat meminimalkan piutang tidak tertagih, karena piutang yang tidak tertagih merupakan masalah pelik.

Bagi semua perusahaan termasuk koperasi, piutang tidak tertagih akan mengurangi modal kerja. Di samping itu, piutang tidak tertagih membawa akibat pada semakin tingginya biaya penagihan. Apabila dalam pelaksanaan pengumpulan piutang tidak sesuai dengan standar yang ditetapkan, maka koperasi harus melakukan perbaikan, selain itu pihak manajemen koperasi perlu melakukan analisis ekonomi terhadap piutang yang menyangkut perbandingan antara manfaat dan pengorbanan. Secara ekonomi dapat dibenarkan jika manfaat yang diharapkan lebih besar daripada pengorbanannya. Dengan demikian permasalahan yang diangkat dalam tulisan ini adalah bagaimana koporasi molakukan analisis torhadap kebijakan penjualan kredit yang akan dilakukan untum meminimalkan piutang tidak tertagih.

Tulisan ini mengangkat suatu studi kasus pada sebuah koperasi, kemudian mengkaji kebijakan kredit yang dapat dilakukan oleh koperasi beserta analisis ekonomi untuk mendapatkan manfaat dari kebijakan kredit yang dilakukan. Tujuan penulisan ini adalah menganalisis kebijakan penjualan kredit yang akan dijalankan koperasi sehingga pihak manajer koperasi dapat memutuskan apakah penjualan kredit tersebut 


\section{MANAJEMEN}

layak dijalankan ataukah tetap dengan penjualan tunai. Untuk menganalisis manajemen piutang pada koperasi, terutama bagaimana kebijakan kredit yang akan dijalankan koperasi, penulis melakukan studi kepustakaan (Library Research), yaitu membaca buku-buku manajemen keuangan dan mengaplikasikan rumus-rumus yang berkaitan dengan piutang usaha ke dalam Microsoft Excel sebagai alat bantu analisis dan hasilnya dapat dijadikan sebagai pengambilan keputusan bagi manajer koperasi.

\section{PEMBAHASAN}

Penjualan barang atau jasa yang dilakukan oleh koperasi tidak dituntut pembayaran pada saat terjadinya transaksi penjualan, tetapi memberi kesempatan kepada pembeli untuk membayar pada jangka waktu tertentu yang telah ditetapkan. Istilah piutang (receivable) memiliki pengertian sebagai tagihan-tagihan atau klaim kepada perseorangan, badan ataupun kepada debitor lainnya sebagai akibat dari penjualan barang atau jasa secara kredit, tanpa disertai dengan janji tertulis secara formal, dalam aktivitas perusahaan yang normal biasanya piutang usaha tersebut akan dilunasi dalam jangka waktu kurang dari 1 (satu) tahun, sehingga piutang usaha dapat dikelompokkan dalam aktiva lancar. Menurut Martono (2007:365), pengertian piutang adalah kelonggaran yang diberikan oleh perusahaan kepada para langganan untuk membayar kemudian atas penjualan barang atau jasa pada waktu melakukan penjualan.

Pada saat ini perusahaan lebih banyak memilih untuk melakukan penjualan atas barang atau jasa yang dihasilkannya secara kredit guna menarik para pelanggan dengan memberikan kelonggaran dalam pembayaran, sehingga akan menimbulkan piutang usaha. Oleh karena itu besar kecilnya penjualan kredit akan berpengaruh langsung terhadap jumlah piutang usaha. Bagi banyak perusahaan, pendapatan dari penjualan kredit merupakan unsur terbesar yang berpengaruh langsung terhadap laba bersih perusahaan. Bila suatu pelanggan/perusahaan membeli secara kredit, maka harus diperhitungkan piutang yang ditimbulkan, yang mungkin sebagai unsur yang paling penting dari aktiva lancar. Bila piutang tersebut berhasil ditagih, maka harus dihitung berapa realisasi kas masuknya. Apabila jumlah kas yang ada melebihi jumlah kas yang dibutuhkan segera, maka kelebihan kas tersebut dapat diinvestasikan dalam surat-surat berharga sampai dengan saat dibutuhkan kembali.

Piutang-piutang yang diberikan pada para debitor tersebut otomatis akan menimbulkan tagihan-tagihan, di mana tagihan-tagihan tersebut dapat terjadi karena berbagai sebab seperti misalnya, karena pemberian pinjaman kepada perusahaan, penyerahan saham perusahaan kepada pemegang saham, selain itu yang lebih penting dan biasanya menjadi sumber pendapatan perusahaan yaitu karena adanya penjualan atas barang atau jasa yang dihasilkan perusahaan secara kredit serta sebab-sebab lainnya yang dapat menimbulkan tagihantagihan.

Salah satu cara yang ditempuh oleh koperasi dalam rangka menaikkan transaksi penjualan terutama dengan non-anggota adalah memberikan tenggang waktu pembayaran. Anggota/non-anggota diberikan batasan waktu pembayaran untuk melunasi utang-utangnya. Penjualan secara kredit merupakan upaya untuk meningkatkan (untuk mencegah penurunan) penjualan. Dengan penjualan yang makin meningkat diharapkan laba koperasi akan meningkat. Akan tetapi memiliki piutang juga mengakibatkan berbagai biaya bagi koperasi. Untuk itu koperasi harus melakukan analisis ekonomi tentang piutang. Analisis ekonomi adalah analisis yang bertujuan untuk menilai apakah manfaat memiliki piutang lebih besar atau lebih kecil dari biayanya.

\section{A. Penjualan Kredit Tanpa Kebijakan Diskon}

Sebuah koperasi diasumsikan selama ini menjual barang kepada non-anggota secara tunai. Untuk menaikkan volume penjualan akan dicoba melakukan transaksi secara kredit. Analisis ekonomi dilakukan untuk memutuskan apakah dengan adanya biaya dana, kebijakan penjualan kredit layak dijalankan. Data yang diperlukan untuk analisis tersebut (KASUS I) merupakan data yang dimiliki oleh koperasi, yang terdiri dari penjualan tunai rata-rata per tahun sebesar Rp 350.000.000,00, penjualan dianggarkan sebesar Rp 400.000.000,00, profit margin sebesar $20 \%$, biaya dana sebesar $15 \%$ dan syarat penjualan $\mathrm{n} / 45$.

Dengan menggunakan Microsoft Excel, dapat diselesaikan kasus di atas melalui prosedur berikut: 1. Tambahan keuntungan karena kenaikan penjualan diperoleh dari selisih penjualan yang dianggarkan 
dikurangi penjualan rata-rata. Selanjutnya selisih tersebut dikalikan dengan profit margin. Rumus pada sel $\mathbf{G 1 1}=(\mathrm{E} 6-\mathrm{E} 4)$ * E7. Nilai yang dihasilkan sebesar Rp 10.000.000,00, 2. Perputaran piutang dihitung dengan 360 (jumlah hari dalam satu tahun) dibagi dengan termin penjualan. Rumus pada sel $E 14=360 / E 5$. Nilai yang dihasilkan adalah 8 kali,

3. Rata-rata piutang dengan cara membagi angka penjualan dianggarkan dengan perputaran plutang. Rumus pada sel $E 15=E 6 / E 14$. Nilai yang dihasilkan sebesar Rp 50.000.000,00, 4. Dana yang terserap untuk membiayai piutang dapat dihitung dengan rumus penjualan dikurangi profit margin dan hasilnya dikalikan dengan rata-rata piutang. Rumus pada sel E16 $=11-$ E7) * E15. Nilai yang dihasilkan sebesar $\operatorname{Rp} 40.000 .000,00$,

5. Dana tambahan piutang dihitung berdasarkan biaya dana dikalikan dana untuk membiayai piutang. Rumus pada sel $\mathbf{G 1 7}=\mathrm{E}_{8} * \mathrm{E}_{16}$. Nilai yang dihasilkan sebesar Rp 6.000.000,00

6. Tambahan manfaat bersih dihitung dari selisih antara tambahan keuntungan karena kenaikan penjualan dibandingkan dengan beban dana tambahan piutang. Rumus pada sel $\mathrm{C18}=\mathrm{G11}-\mathrm{G17}$. Nilai yang dihasilkan sebesar Rp $4.000 .000,00$

7. Analisis ekonomi dari kasus tersebut dapat disimpulkan dengan sebuah rumus pada sel B21 = IF(G18>0; "Kebljakan layak dijalankan:"Kebijakan tidak layak dijalankan"). Artinya jika tambahan manfaat bersih lebih besar daripada nol secara ekonomi kebijakan tersebut. dapat dibenarkan.
Hasil yang diperolch setelah melakukan analisis dengan menggunakan Microsoft Excel dapat dilihat pada gambar 1 berikut.

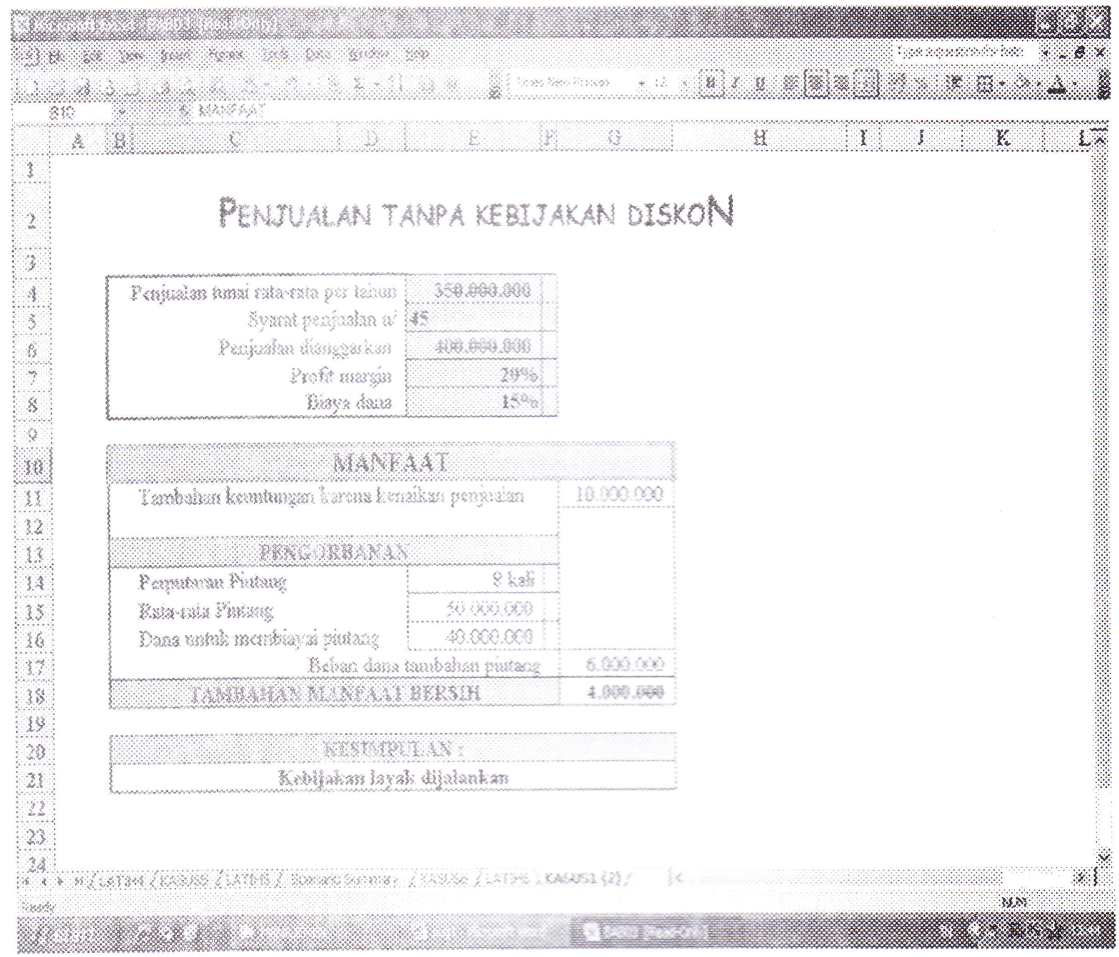

Gambar 1. Penjualan Kredit tanpa Diskon

Dari gambar tersebut kebijakan di atas layak dijalankan karena memberi tambahan manfaat sebesar

Rp 4.000.000,00 (positif)

\section{A. Penjualan Kredit Dengan Kebijakan Diskon}

Salah satu cara yang banyak dilakukan oleh pelaku bisnis untuk menaikkan volume penjualan adalah dengan kombinasi pembayaran secara kredit dan pemberian potongan atau diskon. Namun demikian kebijakan semacam ini sangat berisiko sehingga sebelum memutuskan sebaiknya dilakukan kajian ekonomi terlebih dahulu untuk memutuskan layak tidaknya kebijakan yang akan diambil.

Untuk menganalisis penjualan kredit dengan kebijakan diskon, digunakan data pada KASUS I dengan tambahan termin penjualan 2/20 - n/60. Dengan adanya diskon, maka diperkirakan sebagian konsumen membayar dalam periode diskon dan di luar periode diskon. Keputusan yang dapat diambil dari analisis ini adalah apakah sebaiknya perusahaan memberikan diskon untuk menaikkan volume perijualan atau menjual barang dengan cara kredit tanpa diskon.

Prosedur yang dilakukan dalam penyelesaian kelayakan penjualan kredit dengan diskon adalah sebagai berikut: 
1. Rata-rata periode pembayaran piutang dihitung berdasarkan data pada range E7:E8 dan range E11:E12. Rumus pada Sel E15 $=\left(E 7^{*} E 11\right)+\left(E 8^{*} E 12\right)$. Nilai yang dihasilkan adalah 44 hari. 2. Perputaran piutang dihitung dengan 360 dibagi dengan rata-rata periode pembayaran piutang. Rumus pada sel 3. Rata-rata piutang dihitung berdasarkan penjualan dianggarkan dibagi dengan perputaran piutang. Rumus pada sel E17 =E4 / E16.

Nilai yang dihasilkan sebesar

Rp 48.888.889,00.

4. Dana untuk membiayai piutang dihitung dari penjualan dianggarkan dikurangi profit margin, hasilnya dikalikan dengan rata-rata piutang. Rumus pada sel E18 = $\left(1-\right.$ E9) ${ }^{*}$ E17. Nilai yang dihasilkan sebesar Rp 39.111.111,00.

5. Penurunan biaya dana dihitung berdasarkan pada selisih rata-rata piutang dengan dana untuk membiayai piutang dan hasilnya dikalikan dengan persentase biaya dana. Rumus pada sel $\mathbf{G 1 9}=(\mathbf{E} 17-\mathrm{E} 18) * \mathbf{E} 10$. Nilainya sebesar Rp. 1.466.667,00.

6 . Diskon yang dimanfaatkan konsumen dicari dengan diskon pada syarat penjualan dikalikan perkiraan membayar dalam periode potongan dan hasilnya dikaitkan dengan penjualan dianggarkan. Rumus pada sel G22 = E6* E11*E14. Nilainya sebesar Rp. $3.200 .000,00$

7. Manfaat bersih merupakan selisih antara penurunan biaya dana dengan diskon yang dimanfaatkan konsumen. Rumus pada sel G23 = G19 - G22 Nilainya sebesar (Rp. 1.773.333,00)

Hasil yang diperoleh setelar melakukan analisis dengar menggunakan Microsoft Excel dapa dilihat pada gambar berikut .

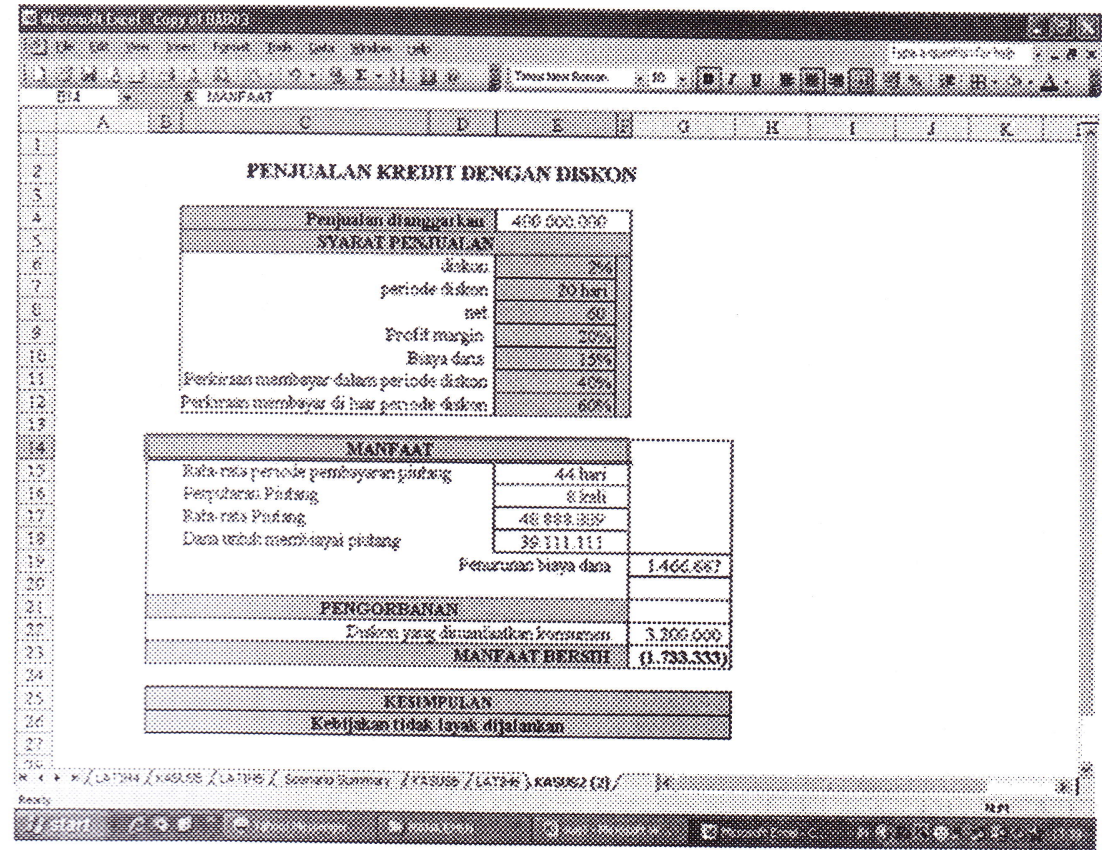

Gambar 2. Penjualan Kredit dengan Diskon

Berdasarkan hasil analisis sebagaimana diperlihatkan pada gambar 2 , ternyata kebijakan penjualan kredit dengan diskon menghasilkan angka negatif (Rp. 1.773.333,00), sehingga kebijakan tersebut tidak layak untuk dijalankan.

Manajer koperasi dapat melakukan uji coba dengan menaikkan profit margin dari $20 \%$ menjadi $30 \%$ dan perkiraan yang membayar dalam periode potongan turun dari $40 \%$ menjadi $25 \%$. Dengan perubahan data tersebut, maka hasilnya diperlihatkan pada gambar 3.

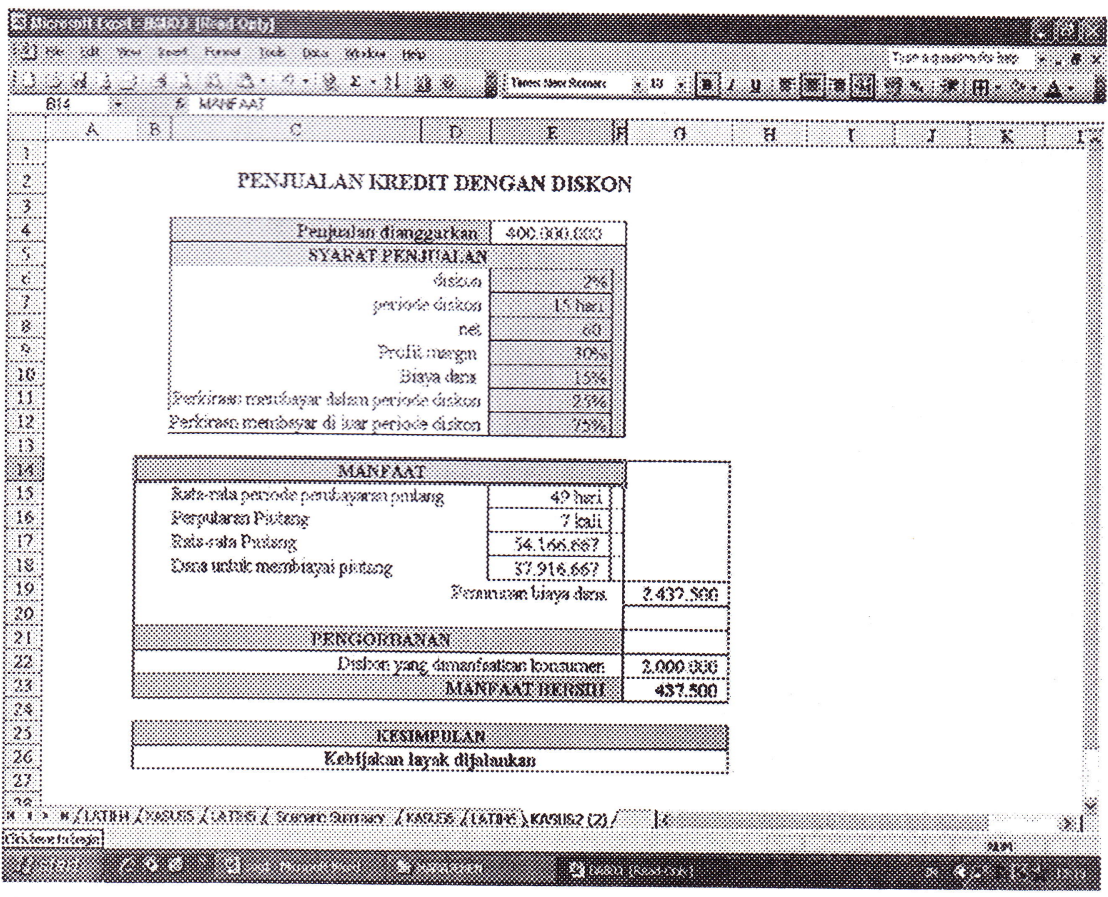

Gambar 3. Penjualan Kredit dengan Diskon (Bila terdapat Perubahan Data) 
Dengan melakukan perubahan data tersebut, maka terlihat manfaat bersih yang diperoleh sebesar $\mathrm{Rp} 437.500,00$ (positif), sehingga kebijakan tersebut layak untuk dijalankan.

\section{A. Penjualan Kredit dan Kerugian Piutang}

Koperasi yang memiliki kebijakan penjualan kredit tanpa diskon sebagai konsekuensinya harus menganggarkan kredit yang tidak tertagih. Persentase piutang yang tidak tertagih dapat ditentukan berdasarkan data historis yang dimiliki oleh suatu koperasi. Kasus berikut ini dapat dipergunakan untuk membuat suatu keputusan apakah koperasi sebaiknya menjual barang (khususnya kepada non-anggota) secara tunai atau secara kredit.

Data historis penjualan kepada non anggota rata-rata per tahun sebesar Rp 400.000.000,00 dan pada tahun depan menganggarkan penjualan sebesar Rp 600.000.000,00. Syarat penjualan kredit ditetapkan $n / 60$ dengan profit margin sebesar $20 \%$ dan biaya dana $15 \%$. Sehubungan dengan penjualan kredit tersebut, maka pihak manajemen koperasi menetapkan besarnya kerugian piutang yaitu $1,5 \%$. Dengan menggunakan aplikasi Microsoft Excel, kebijakan tersebut dapat diketahui layak atau tidaknya dengan menggunakan rumus sebagai berikut:
1. Sel G13 (kenaikan penjualan)
$=(E 7-E 5){ }^{*} E 8$
2. Sel E16 (perputaran piutang) = 360/E6

3. Sel E17 (rata-rata piutang) $=7 / E_{16}$ 4. Sel E18 (dana pembiayaan piutang)= $(1-E 8){ }^{*} E 17$
5. Sel G19 (beban dana tambahan piutang) = E9 * E18

6. Sel G20 (kerugian piutang) $\quad=7^{*} \mathrm{E} 10$

7. Sel G21 (manfaat bersih)

$=$ G13 $-\operatorname{SUM}(\mathrm{G} 19: \mathrm{G} 20)$

Dari masing-masing rumus, maka penyelesaian dari kasus di atas dapat dilihat gambar 4 .

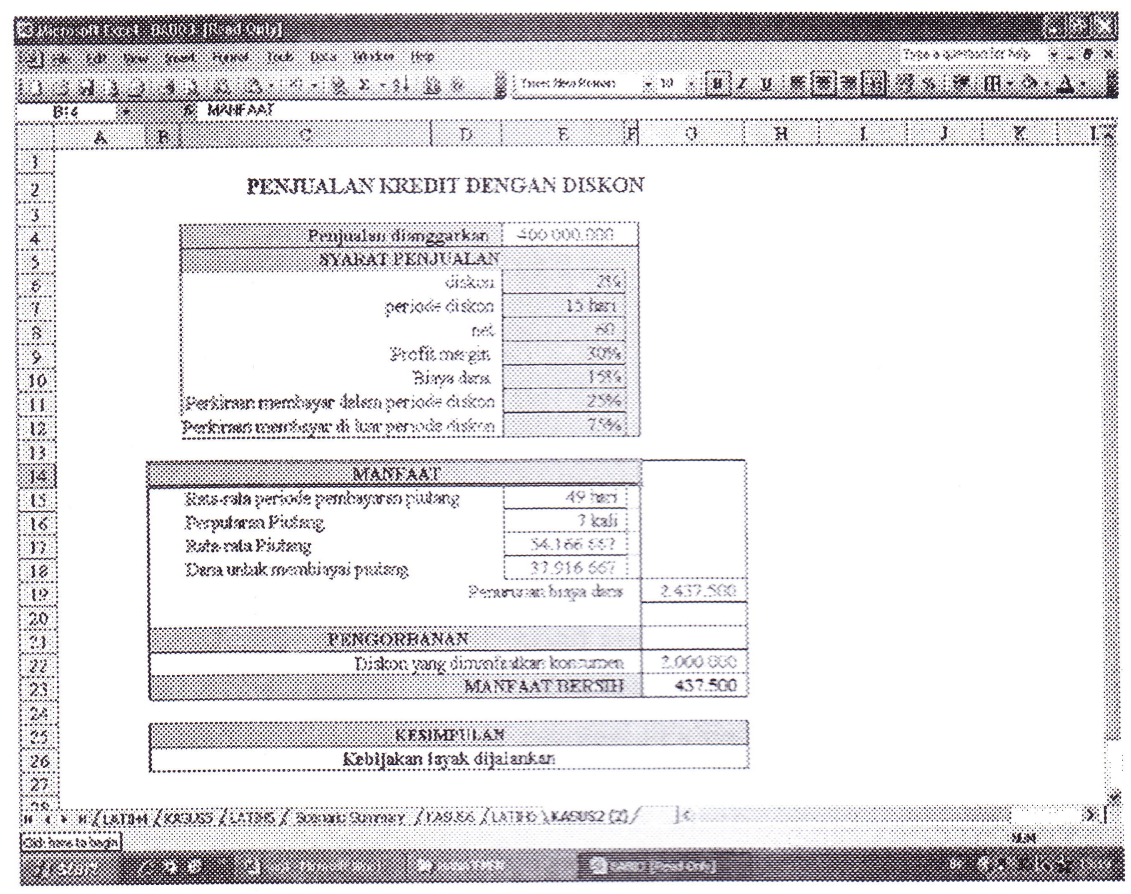

Gambar. 4. Penjualan Kredit dan Kerugian Piutang

Dari gambar 4 di atas, terlihat bahwa kebijakan tanpa diskon yang dilakukan oleh koperasi membawa akibat pengorbanan yang harus ditanggung koperasi sebesar Rp 21.000.000,00 yang terdiri dari beban dana tambahan piutang sebesar $R p 21.000 .000,00$ dan kerugian piutang sebesar Rp 9.000.000,00. Manfaat yang diterima koperasi sebesar Rp 30.000.000,00 yang jauh lebih tinggi dibandingkan dengan pengorbanannya. Oleh karenanya, kebijakan penjualan kredit tanpa diskon layak untuk dijalankan.

\section{PENUTUP}

\section{Kesimpulan}

1. Untuk menaikkan volume penjualan, maka dilakukan penjualan secara kredit terutama bagi non-anggota koperasi. Dengan demikian laba koperasi akan meningkat seiring dengan peningkatan volume penjualan, 2. Penjualan secara kredit mengakibatkan terjadinya piutang usaha di mana piutang usaha merupakan unsur penting dalam aktiva suatu koperasi,

\section{Saran-saran}

1. Perlu dianalisis kebijakan kredit yang akan diterapkan di dalam koperasi untuk menghindarkan dari kerugian yang diakibatkan dari penjualan secara kredit, 


\section{MANAJEMEN}

2. Manajer koperasi perlu melakukan seleksi terhadap non-anggota, sehingga akan terhindarkan dari piutang yang tidak tertagih,

3. Hasil yang diperoleh dari alat bantu analisis tersebut perlu diperhatikan oleh manajer koperasi sebagai pertimbangan dalam pengambilan keputusan tentang kebijakan kredit yang akan dilakukan.

\section{DAFTAR PUSTAKA}

Djatnika, Sri, Ekonomi Koperasi: Teori dan Manajemen, Salemba Empat, Jakarta, 2000.
Kusnadi dan Hendar, Ekonomi Koperasi, Lembaga Penerbit FEUI, Jakarta, 1999

Martono, D. Agus Harjito, Manajemen Keuangan, Ekonosia, Yogyakarta, 2007

Reksohadiprodjo, Sukanto, Business Forecasting, BPFE, Yogyakarta, 2000

Riyanto, Bambang, Dasar-dasar Pembelanjaan Perusahaan, BPFE, Yogyakarta 2001

Winardi, Pengantar Ekonomi Perusahaan, Tarsito, Bandung, 2001

www.google.com

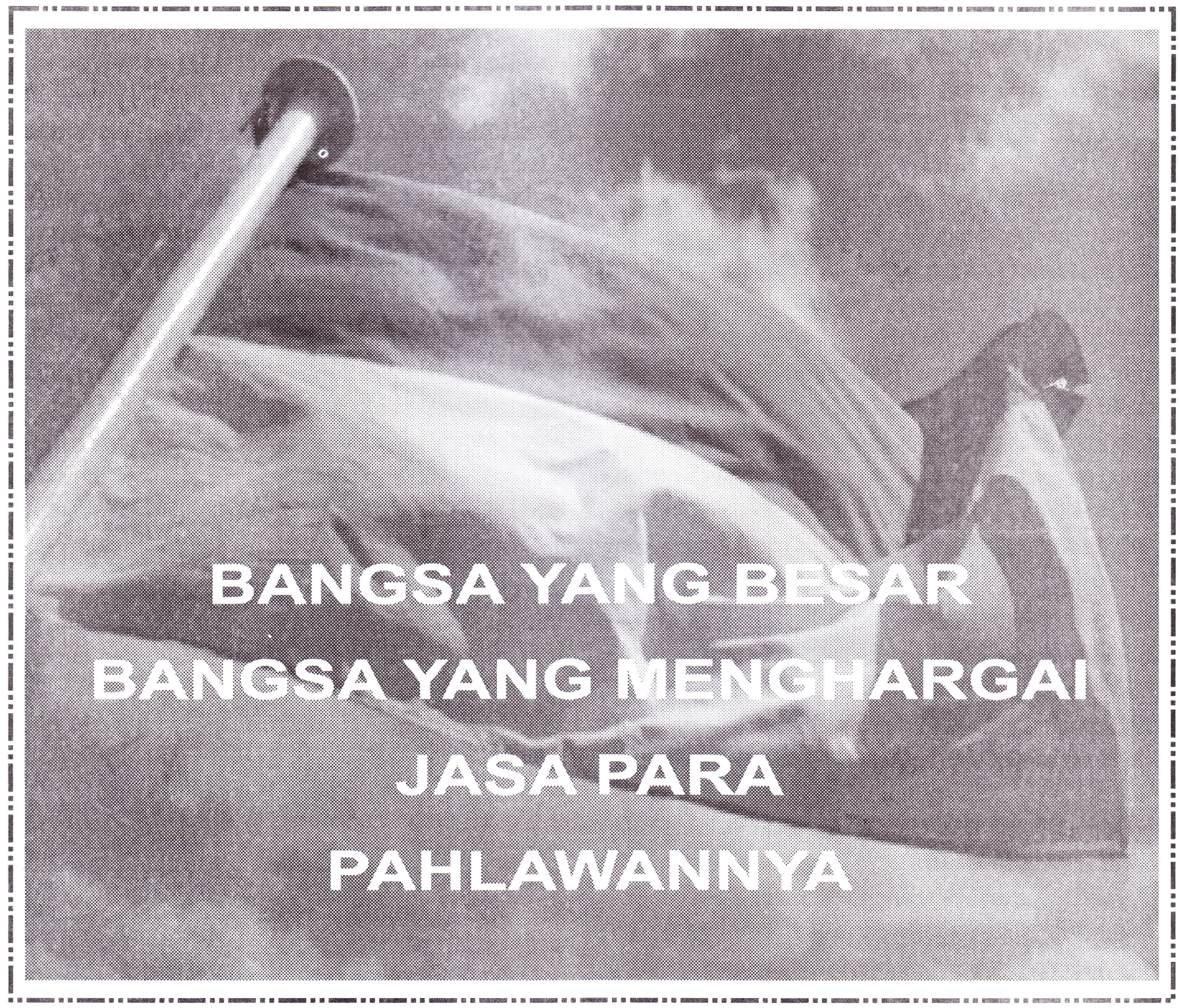

